\title{
Bioactivities of Aeschynomene aspera (Fabaceae) Leaf Extract
}

\author{
Hasnain Imtiaz ${ }^{1}$, Amir Hossain ${ }^{2}$, Fahrima Islam ${ }^{1}$, Razia Sultana $^{3}$ and \\ Md. Mustafizur Rahman ${ }^{1}$
}

${ }^{1}$ Pharmacy Discipline, Life Science School, Khulna University, Bangladesh

${ }^{2}$ Department of Pharmacy, ASA University of Bangladesh, Dhaka, Bangladesh

${ }^{3}$ Descent Specialized Dental Care, Khulna, Bangladesh

(Received: February 19, 2020; Accepted: July 10, 2020; Published (web): July 25, 2020)

\begin{abstract}
Aeschynomene aspera (Family- Fabaceae), a traditionally used medicinal plant, is aquatic, perennial, erect subshrub up to $200 \mathrm{~cm}$ tall with compound leaves and locally it is called Shola (Bangladesh), Laugaun (India). The study started with phytochemical screening of ethanolic leaf extract of A. aspera followed by bioactivity study such as in-vitro antioxidant activity by free radical (DPPH) scavenging assay, estimation of total phenolic as well as total flavonoid contents and the analgesic, antidiarrheal and anthelmintic activities. Analgesic, antidiarrheal and anthelmintic activities were evaluated by acetic acid induced writhing inhibition in mice, castor oil induced diarrheal episode in mice and using living parasites Haemonchus contortus, respectively. The presence of carbohydrate, reducing sugar, glycosides, tannins, alkaloids, steroids, gums and flavonoids was estimated with the help of phytochemical screening. In DPPH scavenging assay the extract showed $\mathrm{IC}_{50}$ value of $86.14 \mu \mathrm{g} / \mathrm{mL}$ where ascorbic acid showed $12.02 \mu \mathrm{g} / \mathrm{mL}$. It also exhibited total phenolic and flavonoid contents as $461.09 \mathrm{GAE} / 100 \mathrm{~g}$ and $297.20 \mathrm{mg}$ Quercetin/100g of dried plant extract. About $36 \%$ and $61 \%$ writhing inhibitions were observed in mice at 250 and $500 \mathrm{mg} / \mathrm{kg}$ doses of A. aspera leaf extract, respectively. Anthelmintic activity showed by the extract was dose dependent. The extract also showed 46.01 and $71.68 \%$ inhibition of defecation in mice at doses 250 and $500 \mathrm{mg} / \mathrm{kg}$, respectively. All these suggest that the $A$. aspera extract possesses antioxidant, analgesic, anthelmintic and antidiarrheal activities.
\end{abstract}

Key words: Aeschynomene aspera, antioxidant, analgesic, antidiarrheal, anthelmintic, mice.

\section{Introduction}

From the ancient world, medicinal plants are exercising for beneficial pharmacological effects on the living body and numerous disorders from fever to infections are found to be healed by these plants (Rahman and Junaid, 2008). Although almost half cent percentage of drugs used in medicine are of plant source, but only a small portion of these plants are analyzed for their medicinal activities (Katiyar et al., 2012). As a matter of fact, natural products are potent therapeutic candidates compared to fully synthetic molecules (Harborne, 1998).

Aeschynomene aspera (Family-Fabaceae), locally called Shola (Bangladesh), Sola (Odia) and
Laugaun (India), is a sub-shrub of swamps. Jaundice, joint pains and swellings are claimed to be healed by its roots and leaves (Padal et al., 2010). The crude extract of the plant is also recommended for painful micturition and to break down uric acid calculi (Caton et al., 2004). Mumps, cold, cough and fever are treated by root and aerial parts. It is also proven that semen consistency is increased by using the crude extract (Panda and Misra, 2011). The plant extract retains glycosides, carbohydrate, tannins, reducing sugar, gums, alkaloids, steroids, and flavonoids as main secondary metabolites. The polyphenolic analysis of the crude extract characterized about 11 compounds (Aruna et al.,

Correspondence to: Md. Mustafizur Rahman; Tel.: +880 1711485602; E-mail: dipti0103@yahoo.com

DOI: https://doi.org/10.3329/bpj.v23i1.48330 
2012). Hepatoprotective activity of A. aspera was also reported (Kumaresan and Pandae, 2011).

Some secondary metabolites of plants like flavonoids and tannins were shown to possess free radical scavenging activity (Meda et al., 2005; Hossain et al., 2016; Sumi et al., 2016), analgesic activity (Mora et al., 1990), and antidiarrheal and anthelmintic (Belemtougri et al., 2006) activities. Based on literature review of the selected plant no report was found on the ethanolic extract of A. aspera leaf. Therefore, we aimed to investigate its possible antioxidant activity and some in vivo activities like analgesic, anthelmintic and antidiarrheal activities.

\section{Materials and Methods}

Plant collection and extraction: A. aspera leaves were collected from Babugonj, Barisal September 2014 and were identified by Bangladesh National Herbarium (Accession No.: DACB-43871), Mirpur, Dhaka-1216. To facilitate extraction, the leaves of this plant were washed using fresh water followed by shade drying for 30 days. Then the dried leaves were crushed into coarse powder with a grinding machine. About $155 \mathrm{~g}$ of the crushed powder was soaked into $800 \mathrm{~mL}$ ethanol for 8 days at room temperature with occasional shaking. The entire combination was then filtered with a piece of white and clean cotton, then with Whatman No. 1 filter paper. The cold extraction gave approximately $5 \%$ yield.

Chemicals: Sodium carbonate and FolinCiocalteus's reagent were obtained from Merck (Damstadt, Germany). 1, 1-dipheny-1-2picrylhydrazyl (DPPH), potassium dichromate, gallic acid (GA), ascorbic acid (AA), $\mathrm{AlCl}_{3}, \mathrm{H}_{2} \mathrm{SO}_{4}$, Nitric acid, $\mathrm{NaOH}$, quercetin (QU), DMSO, EDTA, Diclofenac-Na, sodium nitrous, tween-80 and $\mathrm{FeCl}_{3}$ were obtained from the Sigma Chemical Co.

Phytochemical screening: phytochemicals were identified using various reagents and chemicals such as reducing sugar with Fehling's solution and Benedict's reagent, alkaloid with Mayer's and Dragendroff's reagent, saponins with distilled water, glycosides with sodium hydroxide solution, steroids with $\mathrm{H}_{2} \mathrm{SO}_{4}$, steroids with sulphuric acid, tannin with ferric chloride and potassium dichromate solution, gum with Molisch's reagent (Ghani, 2003; Alif et al., 2018).

DPPH free radical scavenging assay: Quantitative antioxidant activity of A. aspera leaf extract was estimated by DPPH (2, 2-diphenyl-1picrylhydrazyl) free radical scavenging assay (Choi et al., 2000; Islam et al., 2015). In this way, $0.004 \%$ (w/v) DPPH solution was prepared in ethanol and 3 $\mathrm{mL}$ solution of it was mixed with $1 \mathrm{~mL}$ ethanolic crude extract at a different concentration. Subsequently, the mixture was vigorously shaken and kept in a dark place at room temperature for about 30 minutes. Spectrophotometrically absorbance was measured at $517 \mathrm{~nm}$. Percentage scavenging activity was measured by following equation: $\%$ DPPH free radical scavenging activity $=\left[\left(\mathrm{A}_{0}-\mathrm{A}_{1}\right) / \mathrm{A}_{0}\right] \times 100$, where, $A_{0}$ is the absorbance of control, and $A_{1}$ is the absorbance of crude extract/positive control. The \% scavenging activity was then plotted against log concentration and a graph for $\mathrm{IC}_{50}$ was calculated.

Estimation of total phenolics: Total phenolic content was determined using Folin-Ciocalteu technique (Singleton and Rossi, 1965; Raju et al., 2013). In these assays, gallic acid was taken as standard and the result was articulated as gallic acid equivalent, GAE ( $\mathrm{mg}$ of $\mathrm{GA} / \mathrm{g}$ of dried plant extract).

Determination of total flavonoids: A. aspera leaf extract was used for the determination of total flavonoid content (Meda et al., 2005; Amadou et al., 2012). Total flavonoid content was expressed as quercetin equivalent, $\mathrm{QE}(\mathrm{mg}$ of $\mathrm{Q} / \mathrm{g}$ of dried plant extract).

Acetic acid induced writhing inhibition test: Acetic acid induced writhing inhibition method was used to investigated analgesic activity of the leaf extract in swiss albino mice of either sex (Ahmed et al., 2004). Young Swiss-albino mice of any sex with 21-30 gm body weight were used. In this test, before starting the experiment, mice were kept fasted for 2 hours. Mice were divided into four groups, containing 5 mice in each group. Group I was treated with $1 \%$ tween- 80 solution in water $(10 \mathrm{~mL} / \mathrm{kg})$ as the control, Group II received positive control 
(Diclofenac-Na) at a dose of $25 \mathrm{mg} / \mathrm{kg}$ body weight. The group III and IV were set with 250 and 500 $\mathrm{mg} / \mathrm{kg}$ of $A$. aspera leaf extract, respectively. After 30 minutes time interval, $0.7 \%$ acetic acid solution was injected intraperitoneally. After $5 \mathrm{~min}$ of acetic acid injection, the number of abdominal constrictions (writhing) was recorded for a period of $15 \mathrm{~min}$ for each mouse.

Anthelmintic activity test: Live parasites from cattle (Haemonchus contortus) were used to evaluate anthelmintic activity of the crude extract (Ghosh et al., 2005; Hossain et al., 2019). Six (6) parasites were taken in each of the 6 groups. To prepare four doses of extract $(25,50,100$ and $200 \mathrm{mg} / \mathrm{mL}$ of PBS) 0.25 , $0.5,1$ and 2 gm extract were taken and triturated with $0.2 \% \mathrm{v} / \mathrm{v}$ tween 80 and final volume were adjusted to $10 \mathrm{~mL}$. Control group was treated with only $0.1 \%$ tween-80 in PBS to minimize the effect of saline. Ten (10) $\mathrm{mL}$ of control, standard and extract of each concentration were taken in separate petri dishes containing 6 parasites in each and time was observed for paralysis and death of each worm.

Antidiarrheal activity test: Antidiarrheal activity of the extract was evaluated on young Swiss-albino mice weighing between 20 to $29 \mathrm{gm}$ each as described previously (Teke et al., 2007; Hasan et al., 2017). Castor oil was used to provoke diarrhea in mice. These mice were divided into four groups containing five mice in each group. Diarrhea was induced by administering $1 \mathrm{~mL}$ castor oil orally to each mouse. One hour before the administration of castor oil, Group I (control) was given $1 \%$ tween-80 solution in water $(10 \mathrm{~mL} / \mathrm{kg})$ where Group II was administered positive control (standard loperamide) at the dose of $3 \mathrm{mg} / \mathrm{kg}$ body weight, Group-III and Group-IV were given suspension of $A$. aspera leaf extract at oral doses of $250,500 \mathrm{mg} / \mathrm{kg}$ body weight, respectively. Individual mouse of each group was placed in separate cage having blotting paper placed in every cage lined with the floor to examine for the presence of diarrhea every hour for 4 hours after the castor oil administration. Number of stools or any fluid material that stained the blotting paper were counted at each successive hour during the 4 hours' period and was noted for each mouse.

Statistical analysis: All analyses were passed in two replications. Data were produced as mean \pm SEM. Statistical significance levels for most of the investigational parameters were evaluated by correlation and regression analysis, the t-tests $(p<0.05$ and $p<0.01)$. Microsoft Excel 2016 was used for both statistical and graphical presentations.

\section{Results and Discussion}

Phytochemical screening: A. aspera leaf extract undergoes some phytochemical screening tests and confirmed the presence of carbohydrate, reducing sugar, glycosides, tannins, alkaloids, steroids, gums and flavonoids which are recapitulated in Table 1.

Table 1. Secondary metabolites found in ethanol leaf extract of $A$. aspera.

\begin{tabular}{lc}
\hline \multicolumn{1}{c}{ Constituents } & Result \\
\hline Reducing sugar & + \\
Combined reducing sugar & - \\
Tannins & + \\
Flavonoids & + \\
Saponin & - \\
Gums & + \\
Steroids & + \\
Alkaloids & + \\
Glycoside & + \\
Proteins & - \\
Terpenoids & - \\
Acidic compounds & - \\
\hline+ (present); - (absent) &
\end{tabular}

$D P P H$ free radical scavenging activity: In this assay, the extract showed $50 \%$ inhibition $\left(\mathrm{IC}_{50}\right)$ at concentration $86.14 \mu \mathrm{g} / \mathrm{mL}$ whereas standard ascorbic acid showed it at $12.02 \mu \mathrm{g} / \mathrm{mL}$ (Figure 1).

Total phenol and flavonoid content: Total phenolic content was $461.09 \mathrm{mg}$ GAE/100g of crude extract and the total flavonoid content was $297.20 \mathrm{mg}$ $\mathrm{QE} / 100 \mathrm{~g}$ of dried plant extract which is presented in Table 2. 


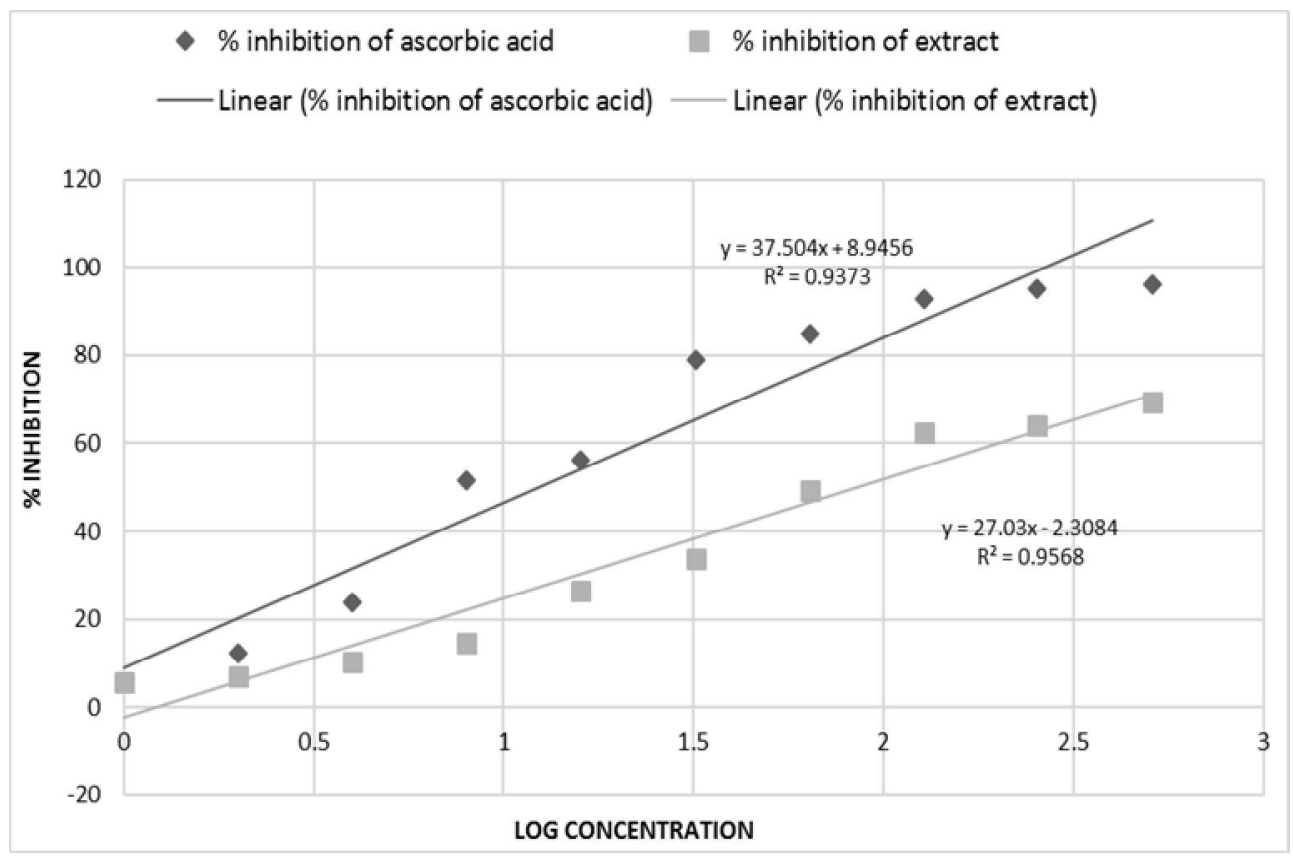

Figure 1. DPPH scavenging activity of $A$. aspera leaf.

Table 2. The total phenolic and flavonoid contents of ethanol leaf extract of $A$. aspera.

Total phenolic and flavonoid compounds
a) Total phenol
$461.09 \pm 0.0027$
b) Total flavonoid
$297.20 \pm 0.004$

Here, each value represents the average of two analyses \pm standard error of mean. a, expressed in terms of mg GAE /100 gm dried plant extract; and b, expressed in terms of $\mathrm{mg} \mathrm{QE} / 100 \mathrm{gm}$ of dried plant extract.

Analgesic activity: The result of analgesic activity of $A$. aspera leaf extract showed a significant inhibition of writhing impulse by $36.23 \%$ and 61.32 $\%$ at the doses of $250 \mathrm{mg} / \mathrm{kg}$ and $500 \mathrm{mg} / \mathrm{kg}$, respectively, where the positive control (Diclofenac Na) exerted $70.03 \%$ writhing inhibition at a dose of $25 \mathrm{mg} / \mathrm{kg}$ body weight (Table 3 ).

Anthelmintic activity: In anthelmintic activity test of $A$. aspera leaf extract, the four concentrations of plant extract $(25,50,100$ and $200 \mathrm{mg} / \mathrm{mL})$ demonstrated paralysis time of 426.67, 294.33,
259.83, 211.33 seconds and death time of 634.33, $435.17,362.67,249.33$ seconds, respectively. On the other hand, standard revealed paralysis time 334.17 , 273.33 seconds and death time at $379.17,338.67$ seconds, respectively (Table 4).

Antidiarrheal activity: A. aspera leaf extract exhibited a significant inhibition of defecation impulse by $46.01 \%$ and $71.68 \%$ at the dose of 250 $\mathrm{mg} / \mathrm{kg}$ and $500 \mathrm{mg} / \mathrm{kg}$, respectively. The positive control, loperamide showed $88.59 \%$ inhibition of defecation at a dose of $25 \mathrm{mg} / \mathrm{kg}$ body weight (Table $5)$.

Medicinal plants, undoubtedly, have a great potential to heal a number of mild to severe diseases. In such a manner, medicinal plants from all around the globe show some pharmacological activities including antioxidant, analgesic, anthelmintic, antidiarrheal activities etc. A. aspera leaf extract approved the presence of carbohydrate, reducing sugar, glycosides, tannins, alkaloids, steroids, gums and flavonoids in its phytochemical screening (Table 1). In several studies, it has been shown that the occurrence of flavonoids and tannins as secondary 
metabolites in plants confirms existence of antioxidants or free radical scavenging activity (Potterat, 1997). Other studies have shown that flavonoids confer analgesic while tannins exert antidiarrheal and anthelmintic activities (Belemtougri et al., 2006) whereas presence of alkaloids in plants possess antibacterial activity (Cushnie et al., 2014).

Table 3. Percentage analgesic activity of $\boldsymbol{A}$. aspera leaves extract in acetic acid induced pain model.

\begin{tabular}{lccc}
\hline Treatment $(n=5)$ & Dose $(\mathrm{mg} / \mathrm{kg})$ & No. of writhes & $\%$ Inhibition \\
\cline { 2 - 4 } Control & $1 \%$ Tween-80 & $28.7 \pm 0.7$ & - \\
Diclofenac sodium & 25 & $8.6 \pm 0.54^{*}$ & 70.03 \\
Extract 250 & 250 & $18.3 \pm 0.7^{* * *}$ & 36.23 \\
Extract 500 & 500 & $11.1 \pm 0.69^{*}$ & 61.32 \\
\hline
\end{tabular}

Values are expressed as mean $\pm \mathrm{SEM}, \mathrm{SEM}=$ Standard error for mean. $n=$ number of mice $(5), *_{p}<0.001$ and $* * p<0.001$ vs. control, Student's t-test.

Table 4. Anthelmintic activity of ethanolic leaves extract of $A$. aspera based on paralysis time and death time.

\begin{tabular}{lccc}
\hline $\begin{array}{l}\text { Treatment } \\
(n=6)\end{array}$ & $\begin{array}{c}\text { Conc. } \\
(\mathrm{mg} / \mathrm{ml})\end{array}$ & \multicolumn{2}{c}{ Time (seconds) taken for paralysis (P) and death (D) } \\
\cline { 2 - 4 } & & $\mathrm{P}$ & $\mathrm{D}$ \\
\cline { 2 - 4 } Control & $0.1 \%$ Tween-80 in PBS & - & - \\
Albendazole 10 & & $334.17 \pm 5.97^{*}$ & $379.17 \pm 6.76^{*}$ \\
Albendazole 15 & 15 & $273.33 \pm 3.57^{*}$ & $338.67 \pm 2.65^{*}$ \\
Extract 25 & 25 & $426.67 \pm 7.94^{*}$ & $634.33 \pm 5.90^{*}$ \\
Extract 50 & 50 & $294.33 \pm 4.07^{*}$ & $435.17 \pm 13.38^{*}$ \\
Extract 100 & 100 & $259.83 \pm 3.73^{*}$ & $342.67 \pm 16.33^{*}$ \\
Extract 200 & 200 & $211.33 \pm 7.06^{*}$ & $249.33 \pm 4.86^{*}$ \\
\hline
\end{tabular}

Values are expressed as mean $\pm \mathrm{SEM}, \mathrm{SEM}=$ Standard error for mean, $n=$ number of parasites $(6), * p<0.001$ vs. control, Student's t-test.

Table 5. Effect of $\boldsymbol{A}$. aspera leaf on castor oil induced diarrhea in mice.

\begin{tabular}{lcccc}
\hline $\begin{array}{l}\text { Treatment } \\
(n=5)\end{array}$ & $\begin{array}{c}\text { Dose } \\
(\mathrm{mg} / \mathrm{kg})\end{array}$ & $\begin{array}{c}\text { Onset of diarrhea } \\
(\mathrm{min})\end{array}$ & $\begin{array}{c}\text { No. of stools after } 4 \\
\text { hours }\end{array}$ & $\begin{array}{c}\text { \% Inhibition of } \\
\text { defecation }\end{array}$ \\
\cline { 2 - 5 } Control & $1 \%$ Tween-80 & $32.2 \pm 1.02^{*}$ & $22.6 \pm 1.51^{*}$ & --- \\
Loperamide & 3 & $198.2 \pm 1.96^{*}$ & $2.60 \pm 0.50^{*}$ & 88.59 \\
Extract 250 & 250 & $83.2 \pm 3.76^{*}$ & $12.2 \pm 0.59^{*}$ & 46.01 \\
Extract 500 & 500 & $152.4 \pm 3.49^{*}$ & $6.4 \pm 0.61^{*}$ & 71.68 \\
\hline
\end{tabular}

Values are expressed as mean $\pm \mathrm{SEM}, \mathrm{SEM}=$ Standard error for mean, $n=$ number of mice $(5), * p<0.001 \mathrm{vs}$. control, Student's t-test.

Hydrogen peroxide, hydroxyl ions and superoxide ions etc. are known as reactive oxygen species (ROS). These are quite a few varieties of activated oxygen that take part in some confronting disorders, for instance cancers, inflammations, coronary heart diseases, aging, neurodegenerative disorders (Huang et al., 2005; Yildirim et al., 2001). In the present study, the crude extract indicated DPPH free radicals scavenging (Fig. 1) activity comparable to ascorbic acid (standard). The intensity 
of decline in absorbance indicates the power of scavenging activity which was seen in case of the extract (Ali et al., 2012).

Plant derived phenolic compounds possess phenylalanine and tyrosine. Some of the plant metabolites are steadily being used in food sector for their high-level phenolic contents as they safeguard lipids from oxidative damage and enhance food quality as well. Presence of hydroxyl groups in phenols increases scavenging capability (Kähkönen et al., 1999; Naczk and Shahidi, 2004). In the present study, the leaf extract contained a good amount of phenolic compound which was $461.09 \mathrm{mg}$ GAE (gallic acid equivalent)/100g dried plant extract (Table 2). On the other hand, flavonoids are exceedingly effective against ROS held responsible for curing numerous diseases in human (Saeed et al., 2012). Presence of flavonoids in the crude extract supports the suitability of the plant in folklore remedies in the treatment of numerous stress related disorders (Grierson and Afolayan, 1999; Ferguson, 2001; Lourens et al., 2004; Mathekga, 2004).

In local tissue injury, different types of chemical mediators for instance, cytokines, leukotrienes and prostaglandins etc. are released and cause pain sensation stimulating nerve terminals (Kanodia and Das, 2009). In analgesic activity assay, acetic acid is used to induce pain by provoking abdominal writhing due to the release of these mediators including prostaglandin (Sulaiman et al., 2008). Our crude extract significantly reduced this acetic acid induced pain in mice evident as writhing inhibition. This finding suggests that the extract exerts analgesic activity probably by blocking synthesis of prostaglandins like mediators.

The anthelmintic activity is an in vitro study that deemed to be the movement failure or paralysis and entire annihilation or death of living parasites (Goto et al., 1990). The polyphenolic compounds like tannins have shown anthelmintic potential by obstructing energy generation of helminths (Robinson et al., 1990). Here, our extract showed significant concentration dependent decrease in both paralysis and death time. The polyphenolics present in the extract might be responsible for the anthelmintic activity.

Medicinal plants have been proven to control gut motility and intestinal transportation. Plant originated compounds have been reported to suppress gut motility, intestinal transit resulting in increased water absorption or reduced intraluminal fluid accumulation (Pérez-Gutiérrez et al., 2013). The leaf extract reduced the total number of feces as well as prolonged the onset of diarrhea significantly and in a dose dependent manner.

\section{Conclusions}

Biochemical evaluation of ethanolic leaf extract of $A$. aspera demonstrated the existence of certain secondary metabolites and possesses to have antioxidant, analgesic, antidiarrheal and anthelmintic activities.

\section{Abbreviations}

DPPH: 1, 1-diphenyl-2-picrylhydrazyl; GA: Gallic acid; AA: Ascorbic acid; QU: Quercetin; SEM: Standard Error Mean; SD: Standard Deviation; PBS: Phosphate Buffered Saline.

\section{Acknowledgments}

The authors are thankful to the Pharmacy Discipline of Khulna University, Khulna, Bangladesh for providing laboratory facilities. We also acknowledge our heartfelt thanks to the Department of Pharmacy, Jahangirnagar University, Savar, Bangladesh for providing experimental mice.

\section{Funding}

Not applicable.

\section{Availability of data and materials}

All data generated or analyzed during this study included in this article are available to other researchers upon request.

\section{Competing interests}

The authors declare that they have no competing interests. 


\section{Ethics approval}

This study was performed after institutional approval of Pharmacy Discipline, Khulna University, Khulna, Bangladesh. The experimental mice were collected from Jahangirnagar University, Savar, Bangladesh.

\section{Declaration of interest}

This statement is to certify that all authors have seen and approved the manuscript being submitted. We warrant that the article is the authors' original work. On behalf of all co-authors, the corresponding author shall bear full responsibility for the submission. This research has not been submitted for publication nor has it been published in whole or in part elsewhere. We attest to the fact that all authors listed on the title page have contributed significantly to the work.

\section{References}

Ahmed, F., Selim, M. S. T., Das, A. K. and Choudhuri, M. S. K. 2004. Anti-inflammatory and Antinociceptive Activities of Lippia nodiflora Linn. Pharmazie. 59, 329-330.

Ali, K., Ashraf, A. and Biswas, N. N. 2012. Analgesic, Anti-inflammatory and Anti-diarrheal Activities of Ethanolic Leaf Extract of Typhonium trilobatum L. Schott. Asian Pac. J. Trop. Biomed. 2, 722-726.

Alif, A., Hossain, A., Hossain, M. A., Madhu, T., Sumi, S., and Rahman, M. M. 2018. Phytochemical and Pharmacological Evaluation of Cyperus odoratus Extract. Bangladesh Pharm. J. 21, 150-159.

Amadou, I., Le, G.-W. and Shi, Y.-H. 2012. Effect of boiling on the cytotoxic and aantioxidant properties of aqueous fruit extract of desert date, Balanites aegyptiaca (L) Delile. Trop. J. Pharm. Res. 11, 437444.

Aruna, C., Chaithra, D., Alekhya, C. and Yasodamma, N. 2012. Pharmacognostic Studies of Aeschynomene indica L. Int. J. Pharm. Pharm. Sci. 4, 1-13.

Belemtougri, R. G., Constantin, B., Cognard, C., Raymond, G. and Sawadogo, L. 2006. Effects of two medicinal plants Psidium guajava L. (Myrtaceae) and Diospyros mespiliformis L. (Ebenaceae) leaf extracts on rat skeletal muscle cells in primary culture. J. Zhejiang Univ. Sci. B 7, 56-63. doi:10.1631/jzus.2006.B0056

Caton, B. P., Mortimer, M., Hill, J. H. and Johnson, D. E. 2004. A practical field guide to weeds of rice in Asia. Int. Rice Res. Inst. (IRRI), Los Baños, Laguna, Philippines p. 116.
Choi, H. Y., Jhun, E. J., Lim, B. O., Chung, I. M., Kyung, S. H. and Park, D. K. 2000. Application of flow injection-chemiluminescence to the study of radical scavenging activity in plants. Phytother. Res. 14, 250253.

Cushnie, T. P. T., Cushnie, B. and Lamb, A. J. 2014. Alkaloids: an overview of their antibacterial, antibiotic-enhancing and antivirulence activities. Int. J. Antimicrob. Agents 44, 377-386.

Ferguson, L. R. 2001. Role of plant polyphenols in genomic stability. Mutat. Res. 475, 89-111. doi:10.1016/s0027-5107(01)00073-2

Ghani, A. 2003. Medicinal Plants of Bangladesh with Chemical Constituents and Uses. Asiatic Society of Bangladesh. Nimtali, Dhaka, pp. 42-48.

Ghosh, T., Maity, T. K., Bose, A. and Dash, G. K. 2005. Anthelmintic activity of Bacopa monierri. Indian J. Nat. Prod. 21, 16-19.

Goto, C., Kasuya, S., Koga, K., Ohtomo, H. and Kagei, N. 1990. Lethal efficacy of extract from Zingiber officinale (traditional Chinese medicine) or [6]shogaol and [6]-gingerol in Anisakis larvae in vitro. Parasitol. Res. 76, 653-656. doi:10.1007/BF00931082

Grierson, D. S. and Afolayan, A. J. 1999. Antibacterial activity of some indigenous plants used for the treatment of wounds in the Eastern Cape, South Africa. J. Ethnopharmacol. 66, 103-106. doi:10.1016/s0378-8741(98)00202-5

Harborne, J. B. 1998. Methods of extraction and isolation. Phytochem. Methods. 3, 60-66.

Hasan, M. M., Hossain, A., Shamim, A. and Rahman, M. M. 2017. Phytochemical and pharmacological evaluation of ethanolic extract of Lepisanthes rubiginosa L. leaves. BMC Complement. Altern. Med. 17, 496.

Hossain, A., Hossain, M. A. and Mannan, S. J. 2019. Evaluation of antioxidant and analgesic activities of three medicinal plants. Pharmacogn. Res. 11, 248253.

Hossain, A., Islam, F., Saifuzzaman, M. Saeed, M. A. S., Islam, M. K., Murshid, G. M. M. and Rahman, M. M. 2016. Bioactivity of Boehmeria macrophylla (Urticaceae) leaf extract. Orient. Pharm. Exp. Med. 16, 233-241.

Huang, D-J., Chen H-J., Lin, C-D., and Lin, Y-H. 2005. Antioxidant and Antiproliferative Activities of Water Spinach (Ipomoea aquatica Forsk) Constituents. Bot. Bull. Acad. Sin. 46, 99-106.

Islam, F., Hossain, A., Hossain, M. G., Murshid, G. M. M. and Rahman, M. M. 2015. Evaluation of antioxidant, analgesic and cytotoxic activities of Typha angustata L. root. Dhaka Univ. J. Pharm. Sci. 14, 55-59. 
Kähkönen, M. P., Hopia A. I., Vuorela, H. J., Rauha, J., Pihlaja, K., Kujala, T. S. and Heinonen, M. 1999. Antioxidant activity of plant extracts containing phenolic compounds. J. Agric. Food Chem. 47, 39543962.

Kanodia, L. and Das, S. 2009. A comparative study of analgesic property of whole plant and fruit extracts of Fragaria vesca in experimental animal models. Bangladesh J. Pharmacol. 4, 35-38.

Katiyar, C., Gupta, A., Kanjilal, S. and Katiyar, S. 2012. Drug discovery from plant sources: an integrated approach. $\quad$ Ayu. $\quad$ 33, $10-19$. https://doi.org/10.4103/0974-8520.100295

Kumaresan, P. and Pandae, V. 2011. Hepatoprotective activity of Aeschynomene aspera Linn. Pharmacologyonline. 3, 297-304.

Lourens, A. C. U., Reddy, D., Başer, K. H. C., Viljoen, A. M. and Van Vuuren, S. F. 2004. In vitro biological activity and essential oil composition of four indigenous South African Helichrysum species. J. Ethnopharmacol. 95, 253-258.

Mathekga, A. D. M. 2004. Antimicrobial activity of Helichrysum species and the isolation of a new phloroglucinol from Helichrysum caespititium. The article was retrieved from: http://hdl.handle.$\underline{\text { net } / 2263 / 23672}$

Meda, A., Lamien, C. E., Romito, M., Millogo, J. and Nacoulma, O. G. 2005. Determination of the total phenolic, flavonoid and proline contents in Burkina Fasan Honey, as well as their radical scavenging activity. Food Chem. 91, 571-577.

Mora, A., Paya, M., Rios, J. L. and Alcaraz, M. J. 1990. Structure-activity relationships of polymethoxyflavones and other flavonoids as inhibitors of nonenzymic lipid peroxidation. Biochem. Pharmacol. 40, 793-797.

Naczk, M. and Shahidi, F. 2004. Extraction and analysis of phenolics in food. J. Chromatogr. 1054, 95-111.

Padal, S. B., Murty, P. P., Rao, D. S. and Venkaiah, M. 2010. Ethnomedicinal plants from Paderu Division of Visakhapatnam District, AP, India. J. Phytol. 2, 70-91.

Panda, A. and Misra, M. K. 2011. Ethnomedicinal survey of some wetland plants of South Orissa and their conservation. Indian J. Traditional Knowledge. 10, 296-303

Pérez-Gutiérrez, S., Zavala-Mendoza, D., HernándezMunive, A., Mendoza-Martínez, A., Pérez-González, C., and Sánchez-Mendoza, E. 2013. Antidiarrheal activity of 19-deoxyicetexone isolated from Salvia ballotiflora Benth in mice and rats. Molecules, 18, 8895-8905.
Potterat, O. 1997. Antioxidants and Free Radical Scavengers of Natural Origin. Curr. Org. Chem. 1, 415-440.

Rahman, M. S. and Junaid, M. 2008. Antimicrobial activity of leaf extracts of Eupatorium triplinerve Vehl. against some human pathogenic bacteria and phytopathogenic fungi. Bangladesh J. Bot. 37, 89-92.

Raju, G. S., Moghal, M. R., Dewan, S. M. R., Amin, M. N. and Billah, M. 2013. Characterization of phytoconstituents and evaluation of total phenolic content, anthelmintic, and antimicrobial activities of Solanum violaceum Ortega. Avicenna J. Phytomed. 3, 313.

Robinson, R. D., Williams, L. A., Lindo, J. F., Terry, S. I. and Mansingh, A. 1990. Inactivation of Strongyloides stercoralis filariform larvae in vitro by six Jamaican plant extracts and three commercial anthelmintics. West Indian Med. J. 39, 213-217.

Saeed, N., Khan, M. R. and Shabbir, M. 2012. Antioxidant activity, total phenolic and total flavonoid contents of whole plant extracts Torilis leptophylla L. BMC Complement. Altern. Med. 12, 221. doi:10.1186/14726882-12-221

Singleton, V. L. and Rossi, J. A. 1965. Colorimetry of total phenolics with phosphomolybdic-phosphotungstic acid reagents. Am. J. Enol. Vitic. 16, 144-158.

Sulaiman, M. R. Hussain M. K., Zakaria Z. A., Somchit N. A., Moin, S., Mohamad, A. S., Israf, D. A. 2008. Evaluation of the antinociceptive activity of Ficus deltoidea aqueous extract. Fitoterapia. 79, 557-561.

Sumi, S. A., Saeed, M. A. S., Hossain, A., Mia, M. S., Afrin, S. and Rahman M. M. 2016. Investigation of the key pharmacological activities of Ficus racemosa and analysis of its major bioactive polyphenols by HPLC-DAD. Evidence-Based Complement. Altern. Med. 1-9.

Teke, G. N., Kuiate, J. R., Ngouateu, O. B. and Gatsing, D. 2007. Antidiarrhoeal and antimicrobial activities of Emilia coccinea (Sims) G. Don extracts. J. Ethnopharmacol. 112, 278-283.

Yildirim, A., Oktay, M. and Bilaloglu. 2001. The antioxidant activity of the leaves of Cydonia vulgaris. Turkish J. Med. Sci. 31, 23-27. 